\title{
Effects on milk urea concentration, urine output, and drinking water intake from incremental doses of potassium bicarbonate fed to mid-lactation dairy cows
}

\author{
T. Eriksson ${ }^{1}$ and B.-O. Rustas \\ Swedish University of Agricultural Sciences, Department of Animal Nutrition and Management, Kungsängen Research Center, SE-753 23 \\ Uppsala, Sweden
}

\begin{abstract}
Large variation exists in the potassium content of dairy cow feeds and also within a feed type due to soil type and fertilization. Increased ration $\mathrm{K}$ concentration causes a subsequent increase in urinary volume and could be expected to also lower milk urea concentration. Six multiparous mid-lactation Swedish Red dairy cows, all fitted with rumen cannulas, were subjected to 3 different levels of $\mathrm{K}$ intake in a Latin square experiment with three 2 -wk periods to evaluate the effects on concentrations of milk urea and rumen ammonia, urinary output, and drinking water intake. The treatments were achieved by $\mathrm{K}$ supplementation on top of a low-K basal ration fed at individual allowances fixed throughout the experiment. The basal ration, consumed at $20.2 \mathrm{~kg}$ of dry matter $(\mathrm{DM}) / \mathrm{d}$, provided $165 \mathrm{~g}$ of crude protein $/ \mathrm{kg}$ of DM and consisted of grass silage, concentrates, and urea in the proportions 39.3:60.0:0.7 on a DM basis. Potassium bicarbonate supplementation was 0,616 , and $1,142 \mathrm{~g} / \mathrm{d}$, respectively, to give total ration $\mathrm{K}$ concentrations that were low (LO; $12 \mathrm{~g} / \mathrm{kg}$ of DM), medium (MED; $23 \mathrm{~g} / \mathrm{kg}$ of DM), or high (HI; 32 $\mathrm{g} / \mathrm{kg}$ of DM). Production and composition of milk was not affected by treatment. A linear effect on milk urea concentration was detected, being 4.48, 4.18, and 3.77 $\mathrm{m} M$ for LO, MED, and HI, respectively, and a linear tendency for rumen ammonia concentration with 6.65, 6.51, and $5.84 \mathrm{mg}$ of $\mathrm{NH}_{3}-\mathrm{N} / \mathrm{dL}$ for $\mathrm{LO}, \mathrm{MED}$, and $\mathrm{HI}$, respectively. Milk urea concentration peaked about 3 $\mathrm{h}$ after the rumen ammonia peak from the morning feeding, at a level $1.3 \mathrm{mM}$ over the baseline. Urinary urea excretion declined linearly $(105,103$, and $98 \mathrm{~g}$ of urea-N/d for LO, MED, and HI, respectively). Linear increases occurred in urinary output $(0.058 \pm 0.001$ $\mathrm{kg}$ of urine/g of $\mathrm{K}$ intake; no intercept; coefficient of determination $=0.997)$ and drinking water intake $(65.9$
\end{abstract}

Received December 20, 2013.

Accepted March 24, 2014.

${ }^{1}$ Corresponding author: Torsten.Eriksson@slu.se $\pm 2.02+0.069 \pm 0.004 \mathrm{~kg}$ of water $/ \mathrm{g}$ of $\mathrm{K}$ intake; coefficient of determination $=0.95$ ). Urinary $\mathrm{K}$ concentration leveled off at $12.4 \mathrm{~g} / \mathrm{L}$. Urinary creatinine excretion was not affected by $\mathrm{K}$ addition, but allantoin excretion increased linearly by $27 \%$ from LO to HI, suggesting increased rumen microbial growth. Rumen $\mathrm{pH}$, acetate proportion of total volatile fatty acids, and digestibility of DM, organic matter, and neutral detergent fiber increased linearly with increasing potassium intake. We concluded that increased ration $\mathrm{K}$ concentration lowers milk urea concentration with a magnitude significant for the interpretation of milk urea values, but other sources of variation, such as sampling time relative to feeding, may be even more important.

Key words: milk urea, potassium, urine volume, water intake

\section{INTRODUCTION}

Milk urea concentration is widely used for monitoring protein nutrition in dairy cows, with the purpose of producing cost-efficient rations that also cause low emissions of $\mathrm{N}$ from animal wastes. Factors that affect milk urea concentration and its relationship to $\mathrm{N}$ excretion have been evaluated in several meta-analyses (Broderick and Clayton, 1997; Jonker et al., 1998; Nousiainen et al., 2004; Spek et al., 2013b), with ration CP concentration being found the main driver of milk urea. However, the considerable effect of experiment (Nousiainen et al., 2004) and the sometimes weak correlation between ration CP and milk urea concentrations (Spek et al., 2013b) suggests that also other factors are important. De Campeneere et al. (2006) reported a $1.0 \mathrm{mM}$ lower milk urea concentration for a perennial ryegrassbased diet compared with a isonitrogenous maize silage diet, a value that increased to $1.5 \mathrm{~m} M$ when mathematically corrected for differences in energy and MP supply and liveweight gain. Those authors explained the difference with the much larger urine volume for the ryegrass diet, which increased the urea clearance rate. Cattle urine volume is to a large extent governed by ration mineral concentration, where $\mathrm{Na}$ and $\mathrm{K}$ are 
the main determinants (Bannink et al., 1999; Nennich et al., 2006; Kume et al., 2008; Weiss et al., 2009). Spek et al. $(2012,2013 \mathrm{a})$ recently showed a linear increase in urine volume, accompanied by a linear decrease in milk urea concentration, with incremental addition of $\mathrm{Na}$ to the diet.

In many dairy cow rations, $\mathrm{K}$ would be the mineral that varies most in concentration. This is because of maize forage generally having a lower $\mathrm{K}$ concentration than grass-legume forage (NorFor, 2013), but also because of large variations within grass-legume forages. The range in K concentration of 13,600 Swedish farm samples of grass-clover silage in the current Nordic Feed Evaluation System (NorFor) feedstuff table was 12 to $32 \mathrm{~g}$ of $\mathrm{K} / \mathrm{kg}$ of $\mathrm{DM}$, when expressed as mean \pm 2 standard deviations (NorFor, 2013). Because urine volume seems to vary to a similar extent with ration $\mathrm{K}$ concentration as with ration $\mathrm{Na}$ concentration, it is likely that it also should induce similar effects on milk urea concentration.

The main objective of the present experiment was to test the hypothesis that incremental $\mathrm{K}$ intake would cause a linear decrease in milk urea concentration. Further objectives were to assess the effects on other measures of $\mathrm{N}$ metabolism and on urine volume and water intake.

\section{MATERIALS AND METHODS}

\section{Animals and Feeding}

The experimental design and all handling of the animals, including surgical procedures, were approved by the Uppsala Local Ethics Committee (Uppsala, Sweden). Six lactating dairy cows of the Swedish Red breed $(618 \pm 38 \mathrm{~kg}$ of BW; DIM $86 \pm 15$ DIM; expressed as mean \pm standard deviation at experimental onset) in the second lactation were used in a $3 \times 3$ Latin square experiment with 6 unique sequences balanced for carryover effects according to design 16.3 of Kuehl (2000). Period length was $14 \mathrm{~d}$, of which d 1 to 9 were used for adaptation and d 10 to 14 were used for sampling. All cows were fitted with rumen cannulas with $100-\mathrm{mm}$ i.d. (Bar Diamond Inc., Parma, ID). The cows were kept throughout the experiment in individual tie-stalls with sawdust bedding, with an empty room between each cow. The water bowls were equipped with water meters (model P-50; Schlumberger Ltd., Montrouge, France). The cows were milked in their stalls at 0600 and $1700 \mathrm{~h}$. The barn temperature was maintained at $12^{\circ} \mathrm{C}$.

A mixed grass-clover ley dominated by timothy grown on an unfertilized organic soil near Uppsala, Sweden $\left(18^{\circ} \mathrm{E}, 60^{\circ} \mathrm{N}\right)$ was harvested for the experiment. The ley was mown with a disc mower on August 15 (7 wk after the first cut), wilted for $3 \mathrm{~d}$ to a target DM of $55 \%$, baled, and wrapped in round bales of approximately $550 \mathrm{~kg}$ fresh weight. At baling, sodium benzoate solution (150 g/L; Medipharm AB, Kågeröd, Sweden) was added at 1 to $2 \mathrm{~L} /$ bale, corresponding to 250 to $500 \mathrm{~g}$ of sodium benzoate/t of fresh weight. All bales were core sampled in the storage and analyzed for DM and mineral content. Thereafter, the 6 bales lowest in $\mathrm{K}$ were later analyzed for $\mathrm{CP}$ and in vitro digestible $\mathrm{OM}$, so that bales of similar composition could be fed during the measurement periods. Before feeding, each bale was thoroughly cut and mixed in a TMR wagon (KD 712; Kverneland Group, Kverneland, Norway).

The basal ration consisted of silage, a commercial concentrate (Solid 620; Lantmännen, Stockholm, Sweden) and urea (AB Johan Hansson, Uppsala, Sweden) in the proportions 39.3:60.0:0.7 on a DM basis. The chemical composition and nutritional value of the feeds is provided in Table 1 . The basal ration was fed from the onset of the experiment with the abovementioned proportions but at individual levels calculated to meet energy demands (Volden, 2011), calculated from previous test milking. This resulted in $10 \%$ orts and feed allowance was hence adjusted before the first sampling period to an amount aiming at zero orts that was fixed for the rest of the trial. Although orts thereafter were about $3 \%$, the consumption was in a steady state from d 7 of the first period. Experimental treatments were the basal ration only [(low $(\mathbf{L O})]$ or the basal ration plus food-grade potassium bicarbonate (Univar Europe, Rotterdam, Netherlands) added to provide double [medium (MED)] or 3-fold [high (HI)] daily potassium intake compared with the basal ration. All feeds were fed manually. Silage was fed with 2 equal meals at 0545 and $1645 \mathrm{~h}$, respectively, with bicarbonate being manually mixed into each individual silage portion before feeding. Concentrates were fed with 4 equal meals in a separate trough at 0600, 0900, 1300, and $1700 \mathrm{~h}$, with urea being manually mixed into the concentrate at the 0600 and $1300 \mathrm{~h}$ feedings. Separate orts of silage and concentrates (concentrate orts occurred from 1 cow only throughout the experiment) were collected immediately before the feedings 0545 and $1645 \mathrm{~h}$, respectively, and weighed once daily.

\section{Sampling and Laboratory Analyses}

Water intake was recorded daily immediately before first feeding. Milk yield was recorded at every milking throughout the experiment (DelPro MU 480 with a MM25WC milk meter; DeLaval International AB, Tumba, Sweden). Milk was sampled at 6 milkings in each period, from the evening milking on $d 1$ through the morning milking on d 14 for analysis of fat, pro- 
Table 1. Composition of experimental feeds

\begin{tabular}{|c|c|c|c|c|}
\hline \multirow[b]{2}{*}{ Item } & \multicolumn{2}{|c|}{ Silage $^{1}$} & \multicolumn{2}{|c|}{ Concentrate $^{2}$} \\
\hline & Mean & SD & Mean & SD \\
\hline \multirow{2}{*}{\multicolumn{5}{|c|}{$\begin{array}{l}\text { DM, } \mathrm{g} / \mathrm{kg} \\
\text { Chemical composition, } \mathrm{g} / \mathrm{kg} \text { of DM }\end{array}$}} \\
\hline & & & & \\
\hline Ash & 58 & 3.2 & 64 & 0.4 \\
\hline NDF & 537 & 16.3 & 232 & 11.2 \\
\hline $\mathrm{iNDF}^{3}$ & 122 & 22 & $45^{4}$ & \\
\hline $\mathrm{CP}$ & 106 & 4.2 & 175 & 0.5 \\
\hline \multicolumn{5}{|l|}{$\mathrm{N}$ fractionation, $\mathrm{g} / \mathrm{kg}$ of $\mathrm{N}$} \\
\hline Soluble N & 400 & 26.9 & 152 & 2.04 \\
\hline $\mathrm{NH}_{3}-\mathrm{N}$ & 42 & 5.0 & 0 & 0 \\
\hline$\alpha$-Amino-N & 188 & 15.9 & 15 & 4.7 \\
\hline \multicolumn{5}{|l|}{ Mineral, $\mathrm{g} / \mathrm{kg}$ of $\mathrm{DM}$} \\
\hline $\mathrm{Ca}$ & 5.27 & 0.40 & 8.02 & 0.04 \\
\hline $\mathrm{P}$ & 1.75 & 0.19 & 5.55 & 0.24 \\
\hline $\mathrm{Mg}$ & 1.24 & 0.09 & 4.31 & 0.09 \\
\hline $\mathrm{K}$ & 19.1 & 0.96 & 7.69 & 0.50 \\
\hline $\mathrm{S}$ & 1.70 & 0.05 & 3.54 & 0.03 \\
\hline $\mathrm{Na}$ & 0.10 & 0.08 & 2.42 & 0.08 \\
\hline \multicolumn{5}{|l|}{ Nutritional value } \\
\hline $\mathrm{AAT}_{\mathrm{N} 20},{ }^{5} \mathrm{~g} / \mathrm{kg}$ of DM & 84 & 2.1 & $121^{4}$ & \\
\hline $\mathrm{PBV}_{\mathrm{N} 20,}, \mathrm{~g} / \mathrm{kg}$ of $\mathrm{DM}$ & -22 & 7.0 & $5^{4}$ & \\
\hline $\mathrm{NE}_{\mathrm{L} 20}{ }^{7} \mathrm{MJ} / \mathrm{kg}$ of DM & 5.50 & 0.16 & $7.31^{4}$ & \\
\hline
\end{tabular}

${ }^{1}$ Grass-clover silage with $\mathrm{pH} 5.73$ and containing (g/kg of DM) the following: lactic acid, 6.7; acetic acid, 3; propionic acid, 1; butyric acid, <0.3; formic acid, 1; ethanol, 2; and 2,3-butanediol, 3.

${ }^{2}$ Solid 620 (Lantmännen, Stockholm, Sweden) containing (g/kg on an as-fed basis): barley, 260; heat-treated rapeseed meal, 180; ground corn, 130; beet pulp, 90; wheat bran, 80; oat bran, 70; malt sprouts, 50; distillers dried grains, 50; mineral and vitamin premix, 50; vegetable fat, 20; and lignosulfonate-treated soybean meal, 20 .

${ }^{3}$ Indigestible NDF.

${ }^{4}$ Tabulated value from manufacturer.

${ }^{5}$ Metabolizable protein at $20 \mathrm{~kg}$ of DMI according to the Nordic Feed Evaluation System (NorFor; Volden, 2011).

${ }^{6}$ Protein balance in the rumen at $20 \mathrm{~kg}$ of DMI according to NorFor (Volden, 2011).

${ }^{7}$ Net energy for lactation at $20 \mathrm{~kg}$ of DMI according to NorFor (Volden, 2011).

tein, lactose, and DM using infrared technology (FT 120; Foss, Hillerød, Denmark) and for urea analysis by colorimetric assay. The samples for infrared analysis were preserved with bronopol, whereas 10-mL duplicate samples for urea analysis were frozen immediately in 14-mL polyethylene tubes without preservative. The urea assay was a standard diacetyl-monoxime procedure (Technicon Instruments Corp., 1974) performed on an AutoAnalyzer III (SEAL Analytical GmbH, Norderstedt, Germany) after removal of fat and protein in the following way: the thawed samples were mixed by inverting them several times and then centrifuged at $3,000 \times g$ for $5 \mathrm{~min}$ in a centrifuge (Hermle Z383K; Hermle Labortechnik GmbH, Wehingen, Germany) set to $4^{\circ} \mathrm{C}$. The tubes were placed in a custom-made Styrofoam block, leaving the upper part of the tube with the fat plug just above the top of the block. The block with the tubes was placed at $-85^{\circ} \mathrm{C}$ in a freezer for 7 to 8 min, whereafter the fat plug was removed with a spoon so that the skim milk could be thawed and decanted into autoanalyzer cups after discarding the top layer that still contained minor fat particles. In addition to the machine-milked samples from morning and evening milkings, time series samples for urea analysis by the same colorimetric assay were taken by strip milking 20 $\mathrm{mL}$ from the left rear teat after the first 3 to 5 squirts had been discarded. The samples were obtained on 11 occasions from morning milking until midnight on d 12 . Two of these occasions and a third separate occasion in each period coincided with the test milkings and were used for assessing the agreement with the samples obtained by machine milking the entire udder.

Daily samples of silage and concentrates were obtained from d 10 to 13 and orts were collected quantitatively from d 11 to 14 and stored at $-20^{\circ} \mathrm{C}$. Feed samples were pooled within feed type and period and orts within cow, feed type, and period. Silage samples and the quantitatively collected silage orts were then milled in a meat mincer while still frozen, whereafter silage orts were carefully sampled to obtain a representative sample for $\mathrm{K}$ analysis. Silage samples were lyophilized (Scanvac CoolSafe CS 95-80 Pro; Labogene 
ApS, Lynge, Denmark), whereas concentrates and orts were dried at $60^{\circ} \mathrm{C}$. The samples were then milled through a 1-mm screen in a hammer mill (Kamas, Malmö, Sweden). Feeds were analyzed for DM, ash, acid-insoluble ash (AIA), ash-free NDF, Kjeldahl N, minerals, and silage OM digestibility by the standard procedures described by Eriksson et al. (2012). Silage orts were analyzed for DM, ash, and mineral content, whereas concentrate orts were analyzed for DM, ash, and Kjeldahl N content. Silage juice was obtained by hydraulic pressing of zip-lock bags containing approximately $100 \mathrm{~g}$ of minced silage that had been soaked with equal weight of deionized water and refrigerated overnight. The extract was analyzed for Kjeldahl N concentration, $\mathrm{pH}$, and fermentation acid concentration with HPLC (Ericson and André, 2010). Soluble N in concentrate samples was analyzed in borate-phosphate buffer with the updated NorFor procedure (Udén and Eriksson, 2012). Both extracts were also subjected to simultaneous analysis of ammonia and $\alpha$-amino- $\mathrm{N}$ on an AutoAnalyzer III (SEAL Analytical GmbH, Norderstedt, Germany). The original setup by Broderick and Kang (1980) was used for ammonia, whereas the ninhydrin assay in the $\alpha$-amino- $\mathrm{N}$ channel was adapted to the dimethyl sulfoxide-hydrindantin chemistry used by Moore (1968).

Quantitative urine collection was made using a natural rubber/latex mold tightly secured over the vulva with a harness (Eriksson et al., 2004). Collection started at $0600 \mathrm{~h}$ on $\mathrm{d} 11$ and continued for $72 \mathrm{~h}$. At container renewal every $12 \mathrm{~h}, 500 \mathrm{~mL}$ of $3.87 \mathrm{M} \mathrm{HCl}$ was added to the container and a further 1,000 $\mathrm{mL}$ was added after a few hours when urine in the container amounted to approximately $5 \mathrm{~L}$. After the first sampling day in period 1 , treatment differences in the required acid amount became obvious, and adapted amounts with, on average, 2.3, 3.0, and $4.0 \mathrm{~L}$ of $3.87 \mathrm{M} \mathrm{HCl}$ were thereafter used for treatments LO, MED, and HI, respectively. At container renewal, the urine was emptied into a tub on a balance to obtain the weight, $\mathrm{pH}$ was measured, and, if necessary, more $\mathrm{HCl}$ was added to reduce urine $\mathrm{pH}$ to $<3$. The urine was then stirred manually and triplicate samples in 14-mL tubes were frozen and stored at $-20^{\circ} \mathrm{C}$ until analysis of urea and creatinine with standard autoanalyzer applications (Eriksson et al., 2004). Period urine composites were prepared for each cow by pooling 4 to $9 \mathrm{~g}$ (in proportion to the fraction of the total amount from the cow that it constituted) of acidified urine from each of the six 12-h container renewals. The composite samples were then used for analysis of Kjeldahl $\mathrm{N}$ and $\mathrm{K}$ by the same methods as for feeds and for allantoin according to George et al. (2006) by HPLC [Alliance 2795 with 2489 UV/visible detector (Waters Corp., Milford, MA); Column Luna $250 \times 4.6 \mathrm{~mm}$ C18 $5 \mu \mathrm{m}$ (Phenomenex Inc., Torrance, CA)]. Density measurements on the composite samples were used when converting volume-based analytical concentrations to total amounts.

Fecal samples (approximately $500 \mathrm{~g}$ ) were obtained at spontaneous defecations twice daily (0530-0800 and 1530-1900 h, respectively), on d 11 to 14 and frozen at $-30^{\circ} \mathrm{C}$. After thawing, the samples were pooled within cow and period and thoroughly mixed with a drill paint mixer, whereafter samples were lyophilized, milled, and analyzed for DM, ash, AIA, NDF, Kjeldahl N, and minerals as described for the feeds.

Ruminal liquid samples were taken at 19 different times during d 11 to 14 , to represent the entire 24-h cycle, although samples in the interval 2000 to $0600 \mathrm{~h}$ were only obtained bihourly. A $50-\mathrm{mL}$ tube was manually inserted approximately $20 \mathrm{~cm}$ below the ruminal surface to be filled with rumen contents within a few seconds. The samples were promptly strained through a tea strainer and $\mathrm{pH}$ was measured (SevenGo SG2; Mettler-Toledo AG, Schwerzenbach, Switzerland; for periods 1 and 2 and because of instrumental damage before the onset of period 3 , the $\mathrm{pH}$ in period 3 was measured by a pHenomenal pH $1000 \mathrm{H}$; VWR International BVBA, Leuven, Belgium). Subsamples in Eppendorf tubes were immediately frozen and stored at $-20^{\circ}$ until analysis of ammonia and $\alpha$-amino- $\mathrm{N}$, as described for feed samples. Samples were pooled within cow and period in proportion to the time interval of the 24-h cycle that the sample represented and analyzed for short-chain FA by HPLC (Ericson and André, 2010).

\section{Calculations and Statistical Analysis}

Tabulated degradation characteristics for grass/clover silage no. 6-478 in the NorFor feed table (NorFor, 2013) were used for calculating standard feed values and individual animal supply of nutrients with NorFor Plan (version 1.19.4.79). Urinary output and urinary concentrations are reported as voided, with $\mathrm{HCl}$ deducted. Fecal excretion for digestibility and balance calculations was from AIA measurements, assuming $100 \%$ AIA recovery.

Balances of $\mathrm{N}$ and $\mathrm{K}$, respectively, were calculated as intake - milk excretion - urinary excretion - fecal excretion. Milk excretion of K was based upon concentrations reported by Gustafson (2001).

Water balance was calculated as drinking water + feed water - milk water - urinary water - fecal water. Milk water was determined by infrared analysis of DM and urinary water was obtained by deducting analyzed compounds (urea, creatinine, and $\mathrm{K}$ ); the unidentified 
urinary $\mathrm{N}$, with an assumed distribution according to Bristow et al. (1992); and $41 \mathrm{~g} / \mathrm{d}$ to represent urinary excretion of minerals other than K (Gustafson, 2001).

An arithmetic mean per cow and period was calculated and used in statistical analysis, except for time series data on rumen variables and strip milking, where periodic mean was calculated as the area under the curve. Periodic mean data were analyzed with PROC MIXED of SAS (version 9.2; SAS Institute Inc., Cary, $\mathrm{NC}$ ) and initially tested for effects of previous treatment and the interaction between treatment and previous treatment. Effect of previous treatment was only recorded for milk protein concentration, for which variable pretreatment was retained in the final model. The final model contained treatment (class variable) as fixed effect and period and cow as random effects. Residuals were tested for normal distribution by PROC UNIVARIATE and for trends by plotting against predicted values. Results are presented as least squares means with standard error of difference and single degree of freedom linear and quadratic contrasts. Probabilities for different least squares means when reported are adjusted with the Tukey adjustment.

Regressions of water intake and urine output against $\mathrm{K}$ intake were performed in PROC MIXED with a random intercept for cow to account for individual levels and coefficients of determination obtained from adjusted $\mathrm{Y}$ values as outlined by St-Pierre (2001). The agreement between milk urea concentration in machine-milked samples and strip-milked samples was assessed by linear regression in PROC GLM of SAS and by calculation of the root mean square prediction error according to Bibby and Toutenburg (1977).

Time series data from ruminal measurements and strip milking were similarly analyzed as repeated measurements with PROC MIXED, with treatment, sampling time, and the interaction treatment $\times$ sampling as fixed factors and cow, period, and the interaction cow $\times$ period as random factors. The $\mathrm{SP}(\mathrm{POW})$ option for covariance structure was used to take into account the time lapse between measurements. The model did not converge for ruminal $\mathrm{pH}$, so covariance parameter estimates from the last iteration were entered into the model again with the PARMS option and the NOPROFILE option was used to get estimates of least squares means and standard error of the difference.

\section{RESULTS}

\section{Intake and Production}

The intake of silage, concentrates, and total basal diet did not differ between the treatments, whereas total DMI differed as planned because of the $\mathrm{KHCO}_{3}$ fed
(Table 2). Except for that and the associated K intake, the only intake differences between the treatments were a linear increase in daily amounts of MP according to NorFor and a subsequent decrease in ruminal protein balance. These changes in calculated nutrient supply were the effects of a predicted increased passage rate and increased microbial protein production from the larger DM intake with $\mathrm{KHCO}_{3}$ addition. In spite of feed allowance being adjusted to minimize orts as described in the Materials and Methods section, moderate silage refusals still occurred. The MED diet indeed provided double the $\mathrm{K}$ intake of the $\mathrm{LO}$ diet, but because of $\mathrm{K}$ in the silage refusals, the $\mathrm{K}$ intake with the $\mathrm{HI}$ diet was not tripled as intended.

No treatment differences were detected regarding milk yield, milk protein yield, or the concentrations of fat, protein, and lactose (Table 3). Both milk urea concentration and total milk urea excretion decreased linearly with increased $\mathrm{K}$ intake. The 2 cows with lowest milk urea concentration deviated from the general linear pattern by having similar values on treatments LO and HI. When morning and evening urea values were analyzed separately (data not shown), the same overall linear effects for concentration were observed, but a more narrow range for evening values (4.10-4.66 $\mathrm{m} M$ ) than for morning values $(3.49-4.33 \mathrm{~m} M)$. Furthermore, total milk urea excretion differed only for the morning values $(66,59$, and $53 \mathrm{mmol} / \mathrm{d}$ for LO, MED, and HI, respectively; $P=0.005$ for linear effect).

\section{Urine and N Balance}

Urine output increased linearly with $\mathrm{K}$ addition (Table 4). Creatinine excretion was similar between diets, whereas a linear effect on allantoin was detected, with allantoin excretion from treatment HI being $27 \%$ higher than from treatment LO. Urinary urea $\mathrm{N}$ excretion declined moderately with increased $\mathrm{K}$. The ratio between urinary urea concentration and milk urea concentration declined linearly for $\mathrm{K}$ addition. Total urinary N excretion showed a quadratic pattern, which was mirrored in the lower $\mathrm{N}$ balance for the MED diet. However, $\mathrm{N}$ balance was actually very high for all diets.

\section{Digestibility and Rumen Parameters}

Digestibility of DM, OM, NDF, and K increased linearly with increased $\mathrm{K}$ intake, whereas $\mathrm{CP}$ digestibility was unaffected (Table 5). A linear increase was detected in the area under the curve of ruminal $\mathrm{pH}$ for the $\mathrm{KHCO}_{3}$ addition (Table 5), with the effect caused by treatment differences occurring from after the morning feeding until the concluding evening measurement at $2215 \mathrm{~h}$ (Figure 1). No treatment effect on 
Table 2. Consumed feeds and nutrients

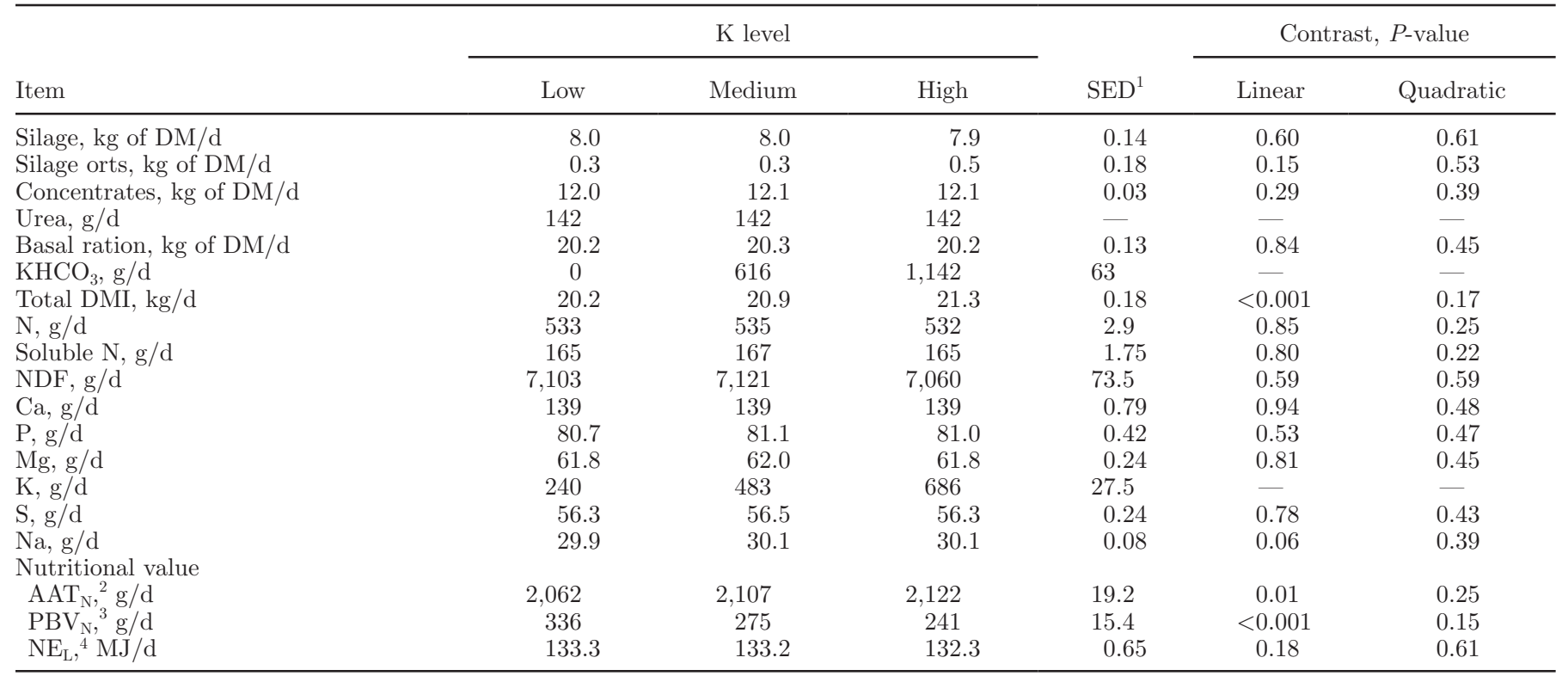

${ }^{1} \mathrm{SED}=\mathrm{SE}$ of the difference.

${ }^{2}$ Metabolizable protein according to the Nordic Feed Evaluation System (NorFor; Volden, 2011).

${ }^{3}$ Protein balance in the rumen according to NorFor (Volden, 2011).

${ }^{4}$ Net energy for lactation according to NorFor (Volden, 2011).

Table 3. Milk production and composition for mid-lactation cows fed incremental amounts of $\mathrm{KHCO}_{3}$ on top of a common basal ration

\begin{tabular}{|c|c|c|c|c|c|c|}
\hline \multirow[b]{2}{*}{ Item } & \multicolumn{3}{|c|}{ K level } & \multirow[b]{2}{*}{$\mathrm{SED}^{1}$} & \multicolumn{2}{|c|}{ Contrast, $P$-value } \\
\hline & Low & Medium & High & & Linear & Quadratic \\
\hline $\mathrm{ECM}, \mathrm{kg} / \mathrm{d}$ & 28.6 & 29.3 & 29.3 & 0.70 & 0.36 & 0.58 \\
\hline Fat, \% & 4.38 & 4.41 & 4.42 & 0.12 & 0.75 & 0.88 \\
\hline Protein, \% & 3.47 & 3.45 & 3.44 & 0.04 & 0.42 & 0.87 \\
\hline Lactose, $\%$ & 4.53 & 4.54 & 4.51 & 0.02 & 0.32 & 0.50 \\
\hline Milk urea, mmol/d & 125 & 117 & 106 & 5.95 & 0.01 & 0.99 \\
\hline
\end{tabular}

${ }^{1} \mathrm{SED}=\mathrm{SE}$ of the difference.

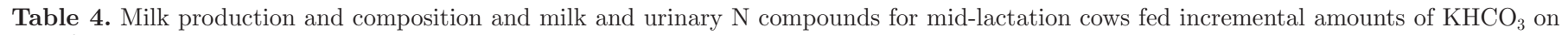
top of a common basal ration

\begin{tabular}{|c|c|c|c|c|c|c|}
\hline Item & \multicolumn{3}{|c|}{ K level } & $\mathrm{SED}^{1}$ & \multicolumn{2}{|c|}{ Contrast, $P$-value } \\
\hline Urine,$^{2} \mathrm{~kg} / \mathrm{d}$ & 14.0 & 27.4 & 39.9 & 2.18 & $<0.001$ & 0.18 \\
\hline Allantoin, g/d & 43.6 & 53.3 & 55.2 & 2.16 & 0.001 & 0.03 \\
\hline Urinary urea N (UUN), g/d & 105 & 103 & 97.5 & 2.31 & 0.01 & 0.66 \\
\hline UUN/MUN ${ }^{2}(\mathrm{~g} / \mathrm{L})$ & 64.0 & 33.7 & 24.4 & 2.28 & $<0.0001$ & $<0.001$ \\
\hline Milk N, g/d & 148 & 150 & 149 & 3.47 & 0.75 & 0.57 \\
\hline $\mathrm{N}$ balance, $\mathrm{g} / \mathrm{d}$ & 99 & 89 & 97 & 4.06 & 0.57 & 0.04 \\
\hline
\end{tabular}

${ }^{1} \mathrm{SED}=\mathrm{SE}$ of the difference.

${ }^{2}$ Urinary output and concentrations as voided, $\mathrm{HCl}$ deducted. 
Table 5. Digestibility and ruminal characteristics for mid-lactation cows fed incremental amounts of $\mathrm{KHCO}_{3}$ on top of a common basal ration

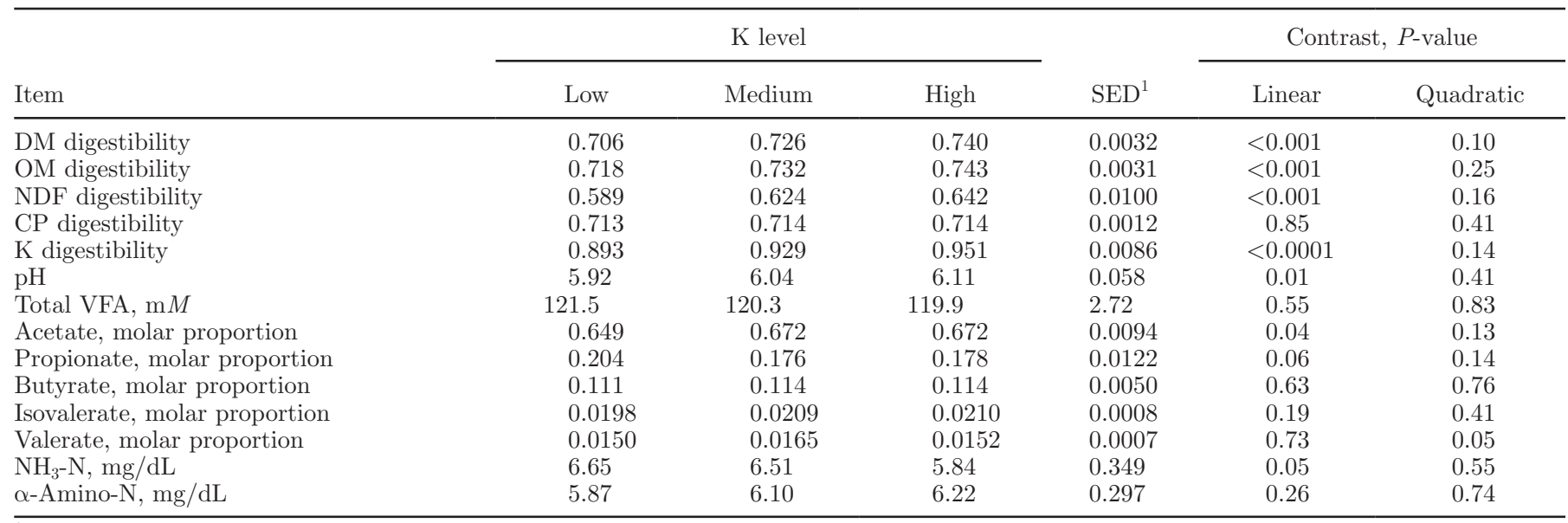

${ }^{1} \mathrm{SED}=\mathrm{SE}$ of the difference.

total ruminal VFA concentration was detected, but an interchange occurred between acetate and propionate (Table 5). Acetate proportion increased with $\mathrm{KHCO}_{3}$ addition and propionate proportion tended to decrease, although both those changes occurred between LO and MED treatments only. Other VFA were not affected, except for a minor quadratic effect on valerate. Ruminal ammonia concentration tended to decrease linearly for increased $\mathrm{KHCO}_{3}$ addition, whereas no effects on the $\alpha$-amino- $\mathrm{N}$ concentration were detected.

\section{Diurnal Nitrogen Variation}

Milk urea concentration in milk samples obtained by ordinary machine milking were overall in good agreement with strip-milked samples obtained immediately before starting test milking, with a root mean square prediction error of $0.38 \mathrm{mM}$ (Figure 2). Figure 2 also il- lustrates the range of values encountered in the experiment (2.26-7.07 $\mathrm{m} M$ and 2.48-6.11 $\mathrm{m} M$ for strip-milked samples and machine-milked samples, respectively), including the variation among individuals. The diurnal milk urea pattern showed an increase after the morning feeding, with a peak $1.3 \mathrm{~m} M$ higher than the morning baseline and then a return to a new baseline about 0.7 $\mathrm{m} M$ above the morning baseline (Figure 3 ). This baseline was then maintained without peaks until declining at the $2200 \mathrm{~h}$ sampling. Rumen $\mathrm{NH}_{3}-\mathrm{N}$ concentration had 2 peaks about $20 \mathrm{mg} / \mathrm{dL}$ over the baseline following the urea fortified meals and a $6 \mathrm{mg} / \mathrm{dL}$ peak after the last silage and concentrate meal. Peaks for $\alpha$-amino-N concentration appeared after the silage meals.

\section{Water Turnover and K Balance}

The slope for urine excretion against $\mathrm{K}$ intake was $0.058\left( \pm 0.001 ; P<0.0001 ; \mathrm{R}^{2}=0.997\right) \mathrm{kg}$ of urine $/ \mathrm{g}$ of

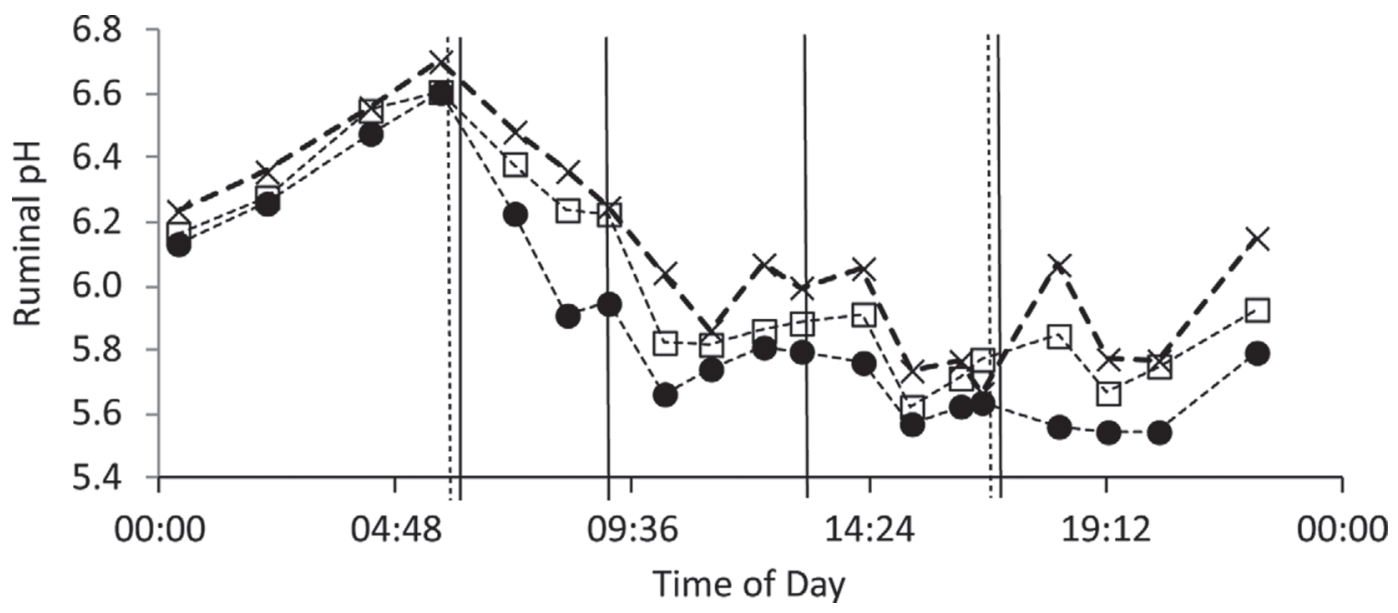

Figure 1. Diurnal variation in ruminal pH for mid-lactation cows consuming zero $(\bullet)$, intermediate $(\square ; 616 \mathrm{~g} / \mathrm{d})$, or high $(\mathrm{X} ; 1,142 \mathrm{~g} / \mathrm{d})$ amounts of $\mathrm{KHCO}_{3}$. Dashed lines indicate silage meals including $\mathrm{KHCO}_{3}$ addition and solid lines indicate concentrate meals (fortified with urea for the 0600 and $1300 \mathrm{~h}$ meals). The largest SE of the difference was $0.11 \mathrm{pH}$ units. 


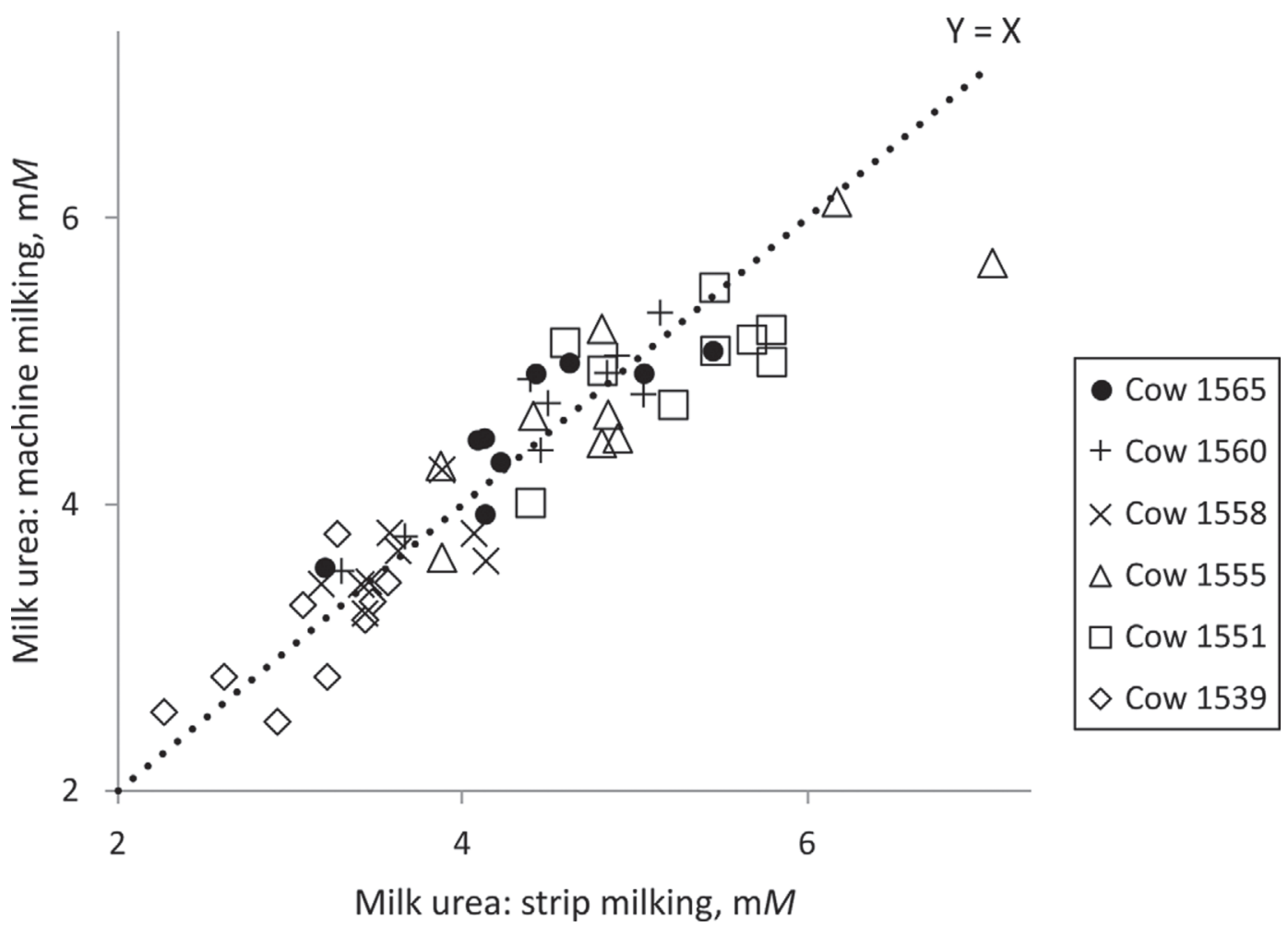

Figure 2. Milk urea concentration in samples obtained by ordinary test milking equipment plotted against milk urea concentration in stripmilked samples of the first milk (20-mL samples collected after discarding the first 3 to 5 squirts) from the left rear teat taken immediately before starting machine milking at 3 occasions in each period. All samples were analyzed by the same colorimetric assay. Simple linear regression: $\mathrm{Y}=$ $0.78( \pm 0.21)+0.81( \pm 0.05) \mathrm{X}\left(\mathrm{R}^{2}=0.84 ; \mathrm{n}=54\right)$.

$\mathrm{K}$, with no significant intercept. Drinking water intake (Table 6) increased linearly in the same manner, but the slope for drinking water was $0.069( \pm 0.004 ; P<$ $\left.0.0001 ; \mathrm{R}^{2}=0.95\right) \mathrm{kg}$ of water $/ \mathrm{g}$ of $\mathrm{K}$, with an intercept of $65.9( \pm 2.02 ; P<0.0001) \mathrm{kg}$. Water balance increased linearly, with a $4.8 \mathrm{~kg} / \mathrm{d}$ difference between treatments MED and HI. Urinary K concentration increased from treatment LO to treatment MED, but was then constant and total fecal $\mathrm{K}$ excretion behaved in the same way (Table 6 ). The $\mathrm{K}$ balance increased linearly.

\section{DISCUSSION}

\section{Milk Urea}

The decrease in milk urea concentration for increased K intake was very similar to what Spek et al. (2012, 2013a) found for increased Na intake (Figure 4). The slope for treatment means of milk urea $(\mathrm{m} M)$ concentration plotted against intake of $\mathrm{Na}+\mathrm{K}(\mathrm{mol} / \mathrm{d})$ was -0.062 in the current experiment, whereas the 3 corresponding slopes for the treatment means reported by Spek et al. (2012, 2013a) could be calculated to be in the range -0.059 to -0.085 . Experimental outcomes were even more similar, if compensating for different milk yields by instead regressing total milk urea excretion $(\mathrm{mmol} / \mathrm{d})$ on $(\mathrm{K}+\mathrm{Na})$ intake $(\mathrm{mol} / \mathrm{d})$. The slope was then -1.53 for the current experiment and -1.46 to -1.78 in the experiments of Spek et al. (2012, 2013a). This suggests that $\mathrm{K}$ and $\mathrm{Na}$ on a molar basis exhibit the same effects on milk urea excretion.

However, the magnitude of $0.7 \mathrm{~m} M$ decrease in milk urea concentration was less than the $1.0 \mathrm{~m} M$ decrease that De Campeneere et al. (2006) actually found when interchanging perennial ryegrass for maize silage, and only half the reduction of $1.5 \mathrm{~m} M$ they arrived at after mathematically correcting milk urea values for dietary differences in energy supply. Mineral intake was not reported in their experiment, although the increase in urinary volume from 14 to $35 \mathrm{~L} / \mathrm{d}$ with perennial ryegrass indicates a range in mineral intakes close to the current experiment. As both roughage and concentrate feeds differed between the experimental treatments of De Campeneere et al. (2006), the outcome may have been influenced by factors other than ration mineral content.

Meta-analyses on feed factors affecting milk urea concentration have typically investigated the concentration and degradation properties of ration CP 


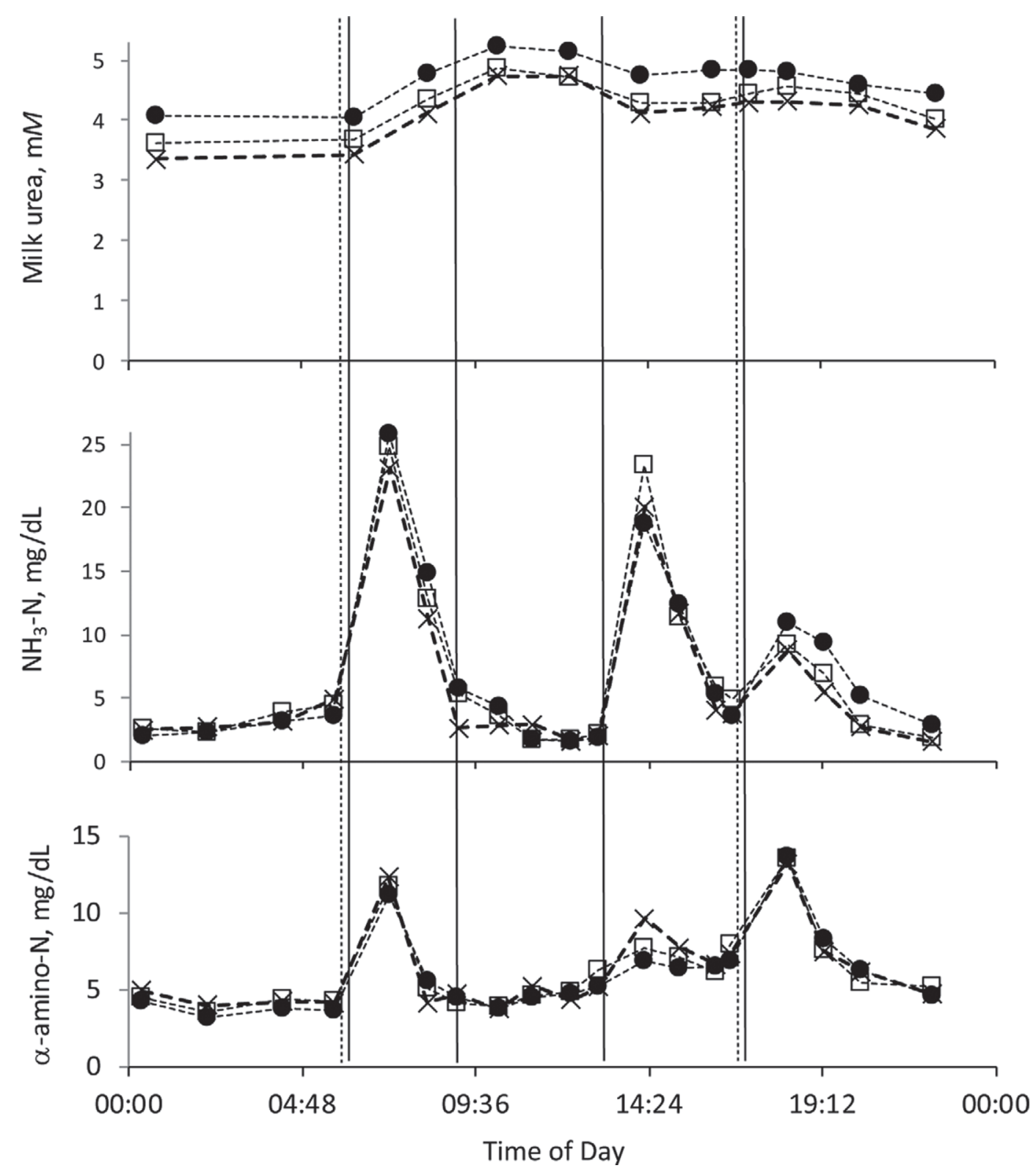

Figure 3. Diurnal variation in the concentrations of milk urea, ruminal liquid $\mathrm{NH}_{3}-\mathrm{N}$, and ruminal liquid $\alpha$-amino- $\mathrm{N}$ for mid-lactation cows consuming low $(\bullet ; 240 \mathrm{~g} / \mathrm{d})$, intermediate $(\square ; 483 \mathrm{~g} / \mathrm{d})$, or high $(\times ; 686 \mathrm{~g} / \mathrm{d})$ amounts of $\mathrm{K}$. Dashed lines indicate silage meals and solid lines indicate concentrate meals (fortified with urea for the 0600 and $1300 \mathrm{~h}$ meals). The largest SE of the difference was $0.19 \mathrm{~m} M \mathrm{milk}$ urea, $2.0 \mathrm{mg}$ of $\mathrm{NH}_{3}-\mathrm{N} / \mathrm{dL}$, and $1.2 \mathrm{mg} \alpha-$ amino- $\mathrm{N} / \mathrm{dL}$.

content, together with the energy supply from different feed constituents (Broderick and Clayton, 1997; Jonker et al., 1998; Nousiainen et al., 2004; Spek et al., 2013b). Ration CP concentration alone has then explained about $80 \%$ of the variation (Broderick and Clayton, 1997; Nousiainen et al., 2004), a value that may increase to $95 \%$ (Nousiainen et al., 2004) if the random effect of the experiment is included in the model. Varying ration mineral concentration would in many feeding trials appear as such a study effect and, depending on the experimental design, give rise to a random intercept (all treatments have about the same mineral concentration) or a random slope (treatments within the experiment differ substantially in their mineral concentration).

The magnitude of the mineral effect on milk urea concentration found in the current experiment could be compared with the total study effect encountered in meta-analyses. Nousiainen et al. (2004) arrived at a root mean square error of $0.63 \mathrm{~m} M$ for the simple linear 
Table 6. Liquid and $\mathrm{K}$ turnover for mid-lactation cows fed incremental amounts of $\mathrm{KHCO}_{3}$ on top of a common basal ration

\begin{tabular}{|c|c|c|c|c|c|c|}
\hline Item & \multicolumn{3}{|c|}{ K level } & $\mathrm{SED}^{1}$ & \multicolumn{2}{|c|}{ Contrast, $P$-value } \\
\hline Drinking water intake, $\mathrm{kg} / \mathrm{d}$ & 82.3 & 98.7 & 113.1 & 2.58 & $<0.001$ & 0.14 \\
\hline Milk water, $\mathrm{kg} / \mathrm{d}$ & 23.7 & 24.2 & 24.2 & 0.50 & 0.33 & 0.50 \\
\hline Fecal water, kg/d & 32.7 & 34.2 & 32.6 & 1.31 & 0.99 & 0.22 \\
\hline Urinary water, $\mathrm{kg} / \mathrm{d}$ & 13.5 & 26.6 & 39.0 & 2.15 & $<0.001$ & 0.19 \\
\hline Urinary K, g/d & 139 & 329 & 476 & 24.93 & $<0.0001$ & 0.047 \\
\hline Fecal K, g/d & 25 & 34 & 33 & 3.28 & 0.04 & 0.08 \\
\hline K balance, $\mathrm{g} / \mathrm{d}$ & 31.9 & 75.0 & 131.5 & 16.27 & $<0.001$ & 0.88 \\
\hline
\end{tabular}

${ }^{1} \mathrm{SED}=\mathrm{SE}$ of the difference.

${ }^{2}$ As voided, corrected for added $\mathrm{HCl}$.

regression of milk urea concentration on ration $\mathrm{CP}$ concentration, of which $0.34 \mathrm{~m} M$ could be ascribed to study effect in that it vanished when study was included in the model. This suggests that the study effect (sources of variation other than ration $\mathrm{CP}$ concentration) should be able to contribute with a variation of approximately $\pm 1 \mathrm{~m} M$ (3 times the part of root mean square error ascribable to study effect) for the extremes outside the $99 \%$ confidence interval in the meta-analysis of Nousiainen et al. (2004). As both positive and negative deviations occur, the span would actually be about $2 \mathrm{~m} M$. This is substantially larger than the range found in the

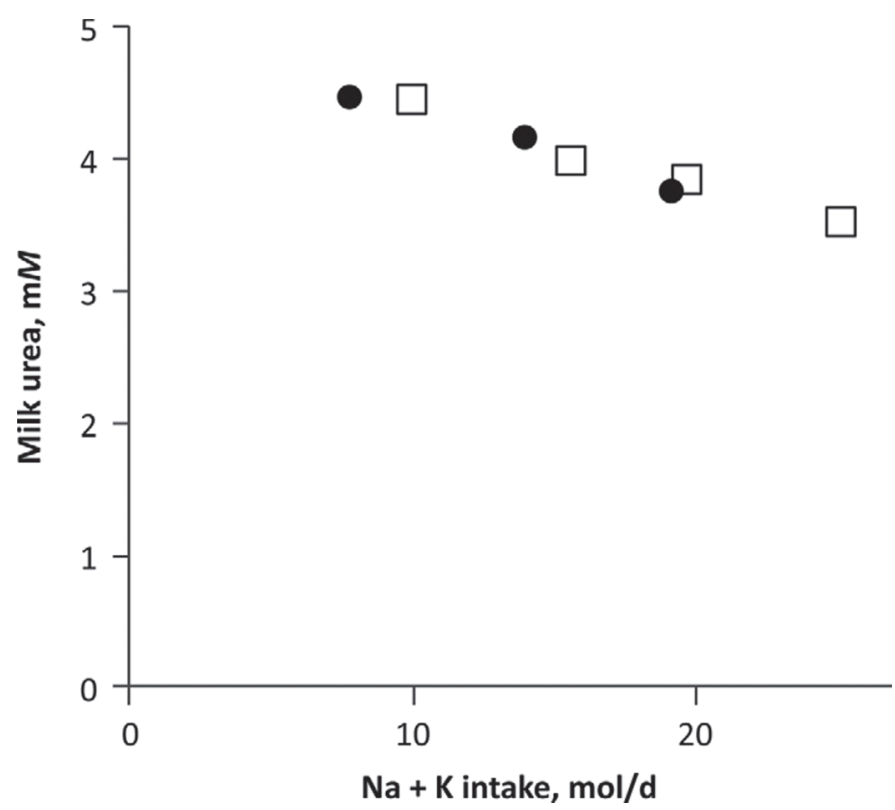

Figure 4. Milk urea concentration as a function of daily $\mathrm{Na}+\mathrm{K}$ intake for mid-lactation cows consuming 519 to $533 \mathrm{~g}$ of N/d and producing 25 to $28 \mathrm{~kg}$ of milk/d. Data from the current experiment ( incremental K amounts) and from Spek et al. (2012; $\square$; incremental dietary Na proportion) are shown. current experiment and does not suggest that varying ration mineral concentration is the major source for the varying response in milk urea concentration to ration $\mathrm{CP}$ concentration encountered in meta-analyses. The leap of $0.71 \mathrm{~m} M$ in the current experiment is the same effect as what could be expected from a decrease in ration $\mathrm{CP}$ concentration of $12 \mathrm{~g} / \mathrm{kg}$ of $\mathrm{DM}$, according to slopes found in meta-analyses on European data (Nousiainen et al., 2004; Spek et al., 2013b). The effect of sampling time for the strip-milked samples was also considerably larger than the treatment effect.

The mean ratio of 41 between concentrations of urinary urea and milk urea, respectively, was relatively similar to previous findings (Gonda and Lindberg, 1994; Broderick and Clayton, 1997). However, the ratios ranged from 24 to 64 , emphasizing that by no means does any constant relationship exist.

\section{N Balance}

The $\mathrm{N}$ balance in the experiment was very high, although even higher values were reported in the review of Spanghero and Kowalski (1997) and in papers by Ruppert et al. (2003) and Moorby et al. (2006) on dairy cow experiments. As digestibility and balance calculations rely upon AIA as a marker, AIA recovery deviating from $100 \%$ would cause erroneous results. Lee and Hristov (2013) recently demonstrated that AIA overestimated the digestibility of CP by 6 to 8 percentage points compared with total collection from highyielding Holstein cows. The NorFor software that was used in the current experiment for calculating nutrient supply on an individual animal basis actually predicted a CP digestibility that was 6 to 7 percentage points lower (data not shown) than the values from AIA in Table 5. That corresponds to 31 to $37 \mathrm{~g}$ more of fecal $\mathrm{N}$ per day and, hence, the same reduction in $\mathrm{N}$ balance. At the same time, OM digestibility was overpredicted 
by about 2 percentage points by NorFor, which suggests specific $\mathrm{N}$ losses rather than OM losses from the fecal samples. A partial explanation could be the analysis of lyophilized and stored fecal samples, which may cause a loss of $22 \mathrm{~g}$ of $\mathrm{N}$ from daily fecal output, according to Spanghero and Kowalski (1997). A substantial amount of $\mathrm{N}$ would still be unaccounted for, but even experiments with total excreta collection and carcass $\mathrm{N}$ analysis of growing lambs failed to recover most of the $\mathrm{N}$ apparently retained according to the $\mathrm{N}$ balance (Early et al., 2001). This has occasionally been ascribed to the loss of elemental $\mathrm{N}$ confirmed in laboratory animals and in man (Costa et al., 1968; Junghans et al., 1999).

\section{Diurnal N Patterns and Effects on $N$ Turnover from Treatments}

Rumen ammonia peaks mainly resulted from the added urea to the experimental rations, where both silage proportions and silage $\mathrm{CP}$ concentrations were low. However, the peaks were very similar in magnitude to what occurs after a silage meal of a typical Scandinavian dairy ration dominated by grass-legume silage (Eriksson, 2010; Eriksson et al., 2012). The fed urea amount would, for instance, correspond to a ruminal liquid concentration of $38 \mathrm{mg}$ of $\mathrm{NH}_{3}-\mathrm{N} / \mathrm{dL}$, if rumen liquid volume is assumed to be $86 \mathrm{~L}$, as in recent rumen evacuations at our laboratory (Eriksson et al., 2012).

The similarity in milk urea concentration between machine-milked and strip-milked samples confirms the conclusion of Gustafsson and Palmquist (1993) that strip milking may be a useful way to assess nutritional status. The pattern of milk urea concentration was similar to what Gustafsson and Palmquist (1993) found, with the urea peak appearing about $3 \mathrm{~h}$ after the morning rumen ammonia peak. The absence of urea peaks after the 1300 and $1700 \mathrm{~h}$ meals may partly be explained by lower intake of $\mathrm{N}$ with these meals, because silage and urea were only provided in conjunction in the morning meal. Reasons for the absence of urea peaks not directly related to feeding may also exist, because Lefcourt et al. (1999) demonstrated circadian rhythms in blood urea concentration that appeared to not be initiated by feeding.

\section{Allantoin Excretion}

The increased allantoin excretion with increased $\mathrm{K}$ intake is most likely explained by higher microbial yield due to less microbial lysis and recycling in the rumen with higher ruminal outflow rate (Russell et al., 1992). Increased outflow rate as the explanatory mechanism would also be in agreement with previous results from our laboratory with cows selected for low or high milk fat concentration but similar production of FCM. Low milk fat concentration was then associated with larger allantoin excretion (Eriksson et al., 2004), larger drinking water intake (Dahlborn et al., 1998), and a tendency toward higher outflow rate (Murphy et al., 2000).

\section{Urine Volume and Water Intake}

With respect to urine volume and water intake, $\mathrm{K}$ may be the most influential mineral in hay crop-based diets, considering both its often high concentration as well as the large variation between different batches (NorFor, 2013). However, Spek et al. (2012) demonstrated an effect of a similar magnitude on urine excretion and water intake with $\mathrm{Na}$ addition to a diet. The similar influence of $\mathrm{Na}$ and $\mathrm{K}$ suggests that the effect on milk urea concentration mirrors the effect on urine volume according to the mechanism proposed by Spek et al. (2012), with a plateau for renal urea reabsorption ratio. The range in urinary excretion in the current experiment with added $\mathrm{KHCO}_{3}$ is similar to measured differences in experiments with hay crop-based diets at our laboratory (Gustafson, 2001; Bertilsson and Murphy, 2003). The slope of $0.058 \mathrm{~kg}$ of urine/g of $\mathrm{K}$ intake was also very similar to the 0.053 previously obtained in a compilation of 23 treatment means from our laboratory (Eriksson, 2011) and actually the very same value that Bannink et al. (1999) reported. This similar effect of added $\mathrm{KHCO}_{3}$ and the $\mathrm{K}$ naturally occurring in feeds on urine volume also suggest that the effect on milk urea concentration may be the same, in spite of $\mathrm{K}$ in plants rather being present as salts of organic acids than as $\mathrm{KHCO}_{3}$ (Van Soest, 1994).

Kume et al. (2008) showed a nonlinear relationship between urinary $\mathrm{K}$ concentration and total urinary $\mathrm{K}$ excretion for dairy cows, with an asymptote at $13 \mathrm{~g} / \mathrm{kg}$. Figure 5 shows the measured urinary K concentrations superimposed on the curve of Kume et al. (2008). At higher $\mathrm{K}$ intake, the variation around the treatment mean decreased. As both total fecal $\mathrm{K}$ excretion and urinary $\mathrm{K}$ concentration were constant between the 2 highest levels of $\mathrm{K}$ intake (Table 6), this suggests that all incremental $\mathrm{K}$ excretion should occur by increased urinary volume. Urine volume should, hence, be possible to predict accurately from $\mathrm{K}$ intake in that range. This concept is further supported by the experiment of Leiber et al. (2009), with a strong correlation for individual lactating cows between DMI and urine volume for a ration with $29 \mathrm{~g}$ of $\mathrm{K} / \mathrm{kg}$ of DM (asymptotic urinary $\mathrm{K}$ concentration reached) but no correlation when the ration contained $12 \mathrm{~g}$ of $\mathrm{K} / \mathrm{kg}$ of $\mathrm{DM}$ (asymptotic urinary $\mathrm{K}$ concentration not reached). 


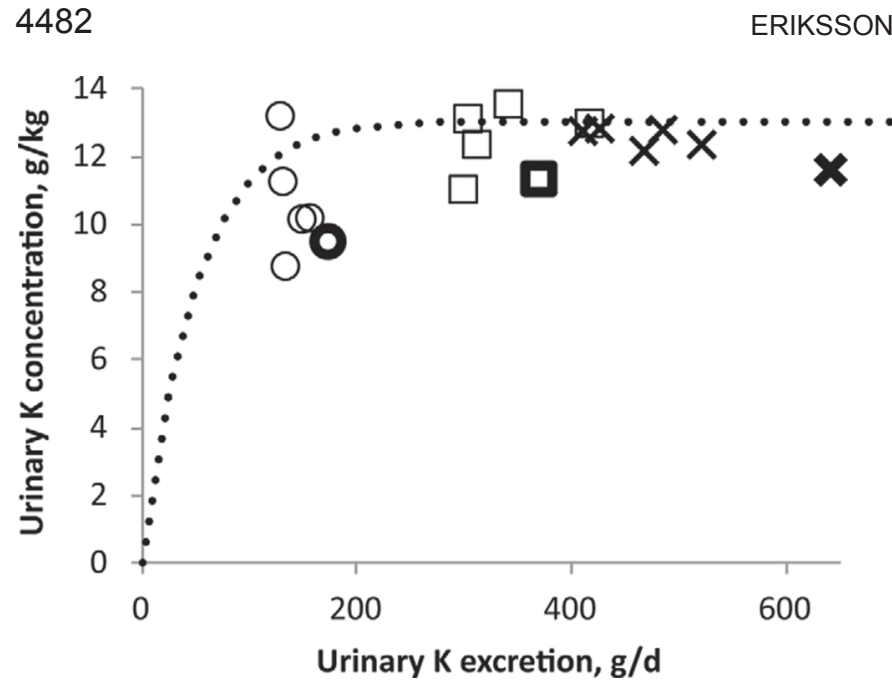

Figure 5. Urinary $\mathrm{K}$ concentration $(\mathrm{g} / \mathrm{kg})$ versus total urinary $\mathrm{K}$ excretion $(\mathrm{g} / \mathrm{d})$ for mid-lactation cows consuming low $(\mathrm{O} ; 240 \mathrm{~g} / \mathrm{d})$, intermediate $(\square ; 483 \mathrm{~g} / \mathrm{d})$, or high $(\times ; 686 \mathrm{~g} / \mathrm{d})$ amounts of $\mathrm{K}$. The dashed line depicts the equation of Kume et al. (2008) and the thick line markers represent cow 1555, consequently having the largest urine amount within each of the treatments.

However, all incremental $\mathrm{K}$ was not recovered in urine and feces, as $\mathrm{K}$ balance increased linearly (Table 6 ). This increment could by no means be accounted for by erroneous estimates of fecal output from the AIA method (corresponds to approximately $15 \mathrm{~kg}$ of extra fecal DM) and hardly by losses of urine, because creatinine excretion was similar for all diets. Excretion of $\mathrm{K}$ in milk was estimated from the concentration reported by Gustafson (2001) and was similar to the values found by Fisher et al. (1994). In fact, Fisher et al. (1994) reported a similar K balance $(125 \mathrm{~g} / \mathrm{d})$ from their experiment including quantitative collection of both feces and urine as well as $\mathrm{K}$ analysis of the milk. However, this was for a diet providing $46 \mathrm{~g}$ of $\mathrm{K} / \mathrm{kg}$ of DM, whereas $32 \mathrm{~g}$ of $\mathrm{K} / \mathrm{kg}$ of DM instead resulted in a negative $\mathrm{K}$ balance of $-78 \mathrm{~g} / \mathrm{kg}$ of DM. Harrison et al. (2012) observed a $\mathrm{K}$ balance up to $303 \mathrm{~g} / \mathrm{d}$ in early-lactation cows, although based upon fecal AIA estimates and urinary output predicted from dietary cation-anion difference. The ambiguous $\mathrm{K}$ balances occurring may, in some cases, partly be explained by sweat losses (Silanikove et al., 1997).

The water balance recorded in the current experiment was similar to what was found by Dahlborn et al. (1998), except for the highest K level. Also the experiment of Fisher et al. (1994) resulted in a linear increase in water balance from approximately $22 \mathrm{~kg}$ to $32 \mathrm{~kg} / \mathrm{d}$ for increased $\mathrm{K}$ addition. These water balances would be at the upper end of results reported from surface and respiratory vaporization experiments (Manalu et al., 1991), especially if the approximately $5 \mathrm{~kg} / \mathrm{d}$ of metabolic water is added to the balance. Although no obvious explanation exists for the linear increase with $\mathrm{K}$ addition, interactions between ion availability and cutaneous water losses (Silanikove et al., 1997) as well as the fecal output estimates from AIA may have been influential.

\section{Digestibility, Rumen Parameters, and Buffering Effects}

A substantial increase was detected in both NDF digestibility and acetate proportion of rumen VFA with $\mathrm{KHCO}_{3}$ addition. Both of these effects may be attributed to the increased ruminal $\mathrm{pH}$, chiefly caused by the bicarbonate ion (Dijkstra et al., 2012). Potassium bicarbonate has occasionally been examined as a buffer in dairy cow rations (Schneider et al., 1984; West et al., 1986), but with no beneficial effect regarding rumen $\mathrm{pH}$ or production. However, the $\mathrm{KHCO}_{3}$ amounts provided in the current experiment (29 and $54 \mathrm{~g} / \mathrm{kg}$ of DM for diets MED and HI, respectively) were considerably higher than the 10 and $18 \mathrm{~g} / \mathrm{kg}$ of DM used by Schneider et al. (1984) and West et al. (1986), respectively. The increased NDF digestibility with $\mathrm{KHCO}_{3}$ addition in the current experiment suggests that ruminal $\mathrm{pH}$ may be suboptimal for fiber digestibility also in many hay crop-based dairy rations, and not only in maizebased diets, as the meta-analysis by $\mathrm{Hu}$ and Murphy (2005) indicated.

\section{CONCLUSIONS}

Increased ration $\mathrm{K}$ concentration lowered milk urea concentration. The magnitude of the effect is of significance for interpretation of milk urea results, but diurnal variation in milk urea concentration was of larger magnitude than the variation caused by different levels of $\mathrm{K}$ intake. Urine volume and drinking water intake increase linearly for increased $\mathrm{K}$ intake and the urinary urea:milk urea ratio may vary with a factor 2.7 by altering $\mathrm{K}$ intake when everything else is held constant.

\section{ACKNOWLEDGMENTS}

This work was funded by The Swedish Farmers' Foundation for Agricultural Research (Stockholm, Sweden). Glen Broderick (University of Wisconsin-Madison) is gratefully acknowledged for constructive suggestions on data interpretation. Sara Johansson and Emelie Carlsson (both from County Administrative Board, Kalmar, Sweden) contributed substantially in planning and performance of the experiment. The skillful technical assistance from Gunilla Helmersson, Lena Hagenvall, Camilla Andersson, Håkan Wallin, and others in the Kungsängen laboratory and Swedish University of 
Agricultural Sciences Livestock Research Centre barn (Uppsala, Sweden) made the experiment possible.

\section{REFERENCES}

Bannink, A., H. Valk, and A. M. van Vuuren. 1999. Intake and excretion of sodium, potassium, and nitrogen and the effects on urine production by lactating dairy cows. J. Dairy Sci. 82:1008-1018.

Bertilsson, J., and M. Murphy. 2003. Effects of feeding clover silages on feed intake, milk production and digestion in dairy cows. Grass Forage Sci. 58:309-322.

Bibby, J., and H. Toutenburg. 1977. Pages 16-19 in Prediction and Improved Estimation in Linear Models. John Wiley \& Sons, London, UK.

Bristow, A. W., D. C. Whitehead, and J. E. Cockburn. 1992. Nitrogenous constituents in the urine of cattle, sheep and goats. J. Sci. Food Agric. 59:387-394.

Broderick, G. A., and M. K. Clayton. 1997. A statistical evaluation of animal and nutritional factors influencing concentrations of milk urea nitrogen. J. Dairy Sci. 80:2964-2971.

Broderick, G. A., and J. H. Kang. 1980. Automated simultaneous determination of ammonia and total amino acids in ruminal fluid and in vitro media. J. Dairy Sci. 63:64-75.

Costa, G., L. Ullrich, F. Kantor, and J. F. Holland. 1968. Production of elemental nitrogen by certain mammals including man. Nature 218:546-551.

Dahlborn, K., M. Åkerlind, and G. Gustafson. 1998. Water intake by dairy cows selected for high or low milk-fat percentage when fed two forage to concentrate ratios with hay or silage. Swed. J. Agric. Res. 28:167-176.

De Campeneere, S., D. L. De Brabander, and J. M. Vanacker. 2006. Milk urea concentration as affected by the roughage type offered to dairy cattle. Livest. Sci. 103:30-39.

Dijkstra, J., J. L. Ellis, E. Kebreab, A. B. Strathe, S. López, J. France, and A. Bannink. 2012. Ruminal pH regulation and nutritional consequences of low pH. Anim. Feed Sci. Technol. 172:22-33. http:// dx.doi.org/10.1016/j.anifeedsci.2011.12.005.

Early, R. J., O. Mahgoub, and C. D. Lu. 2001. Energy and protein utilization for maintenance and growth in Omani ram lambs in hot climates. II. Composition of tissue growth and nitrogen metabolism. J. Agric. Sci. 136:461-470.

Ericson, B., and J. André. 2010. HPLC-Applications for agricultural and animal science. Pages 23-26 in Proc. 1st Nordic Feed Science Conf. Swed. Univ. Agric. Sci., Uppsala, Sweden.

Eriksson, T. 2010. Nitrogen metabolism in dairy cows fed restricted amounts of grass-clover silage supplemented with seeds from narrow-leafed lupin or pea. Livest. Sci. 131:39-44. http://dx.doi. org/10.1016/j.livsci.2010.02.021

Eriksson, T. 2011. Urine excretion relative to K intake in Swedish Red cattle. Pages 15-19 in Proc. 2nd Nordic Feed Science Conf. Swed. Univ. Agric. Sci., Uppsala, Sweden.

Eriksson, T., M. Murphy, P. Ciszuk, and E. Burstedt. 2004. Nitrogen balance, microbial protein production, and milk production in dairy cows fed fodder beets and potatoes, or barley. J. Dairy Sci. $87: 1057-1070$.

Eriksson, T., L. Norell, and N. Nilsdotter-Linde. 2012. Nitrogen metabolism and milk production in dairy cows fed semi-restricted amounts of ryegrass-legume silage with birdsfoot trefoil (Lotus corniculatus L.) or white clover (Trifolium repens L.). Grass Forage Sci. 67:546-558. http://dx.doi.org/10.1111/j.13652494.2012.00882.x.

Fisher, L. J., N. Dinn, R. M. Tait, and J. A. Shelford. 1994. Effect of level of dietary potassium on the absorption and excretion of calcium and magnesium by lactating cows. Can. J. Anim. Sci. 74:503-509.

George, S. K., M. T. Dipu, U. R. Mehra, P. Singh, A. K. Verma, and J. S. Ramgaokar. 2006. Improved HPLC method for the simultaneous determination of allantoin, uric acid and creatinine in cattle urine. J. Chromatogr. B Analyt. Technol. Biomed. Life Sci. 832:134-137. http://dx.doi.org/10.1016/j.jchromb.2005.10.051.
Gonda, H. L., and J. E. Lindberg. 1994. Evaluation of dietary nitrogen-utilization in dairy-cows based on urea concentrations in blood, urine and milk, and on urinary concentration of purine derivatives. Acta Agric. Scand. A Anim. Sci. 44:236-245.

Gustafson, G. M. 2001. Partitioning of nutrient and trace elements in feed among milk, faeces and urine by lactating dairy cows. Acta Agric. Scand. A Anim. Sci. 50:111-120.

Gustafsson, A. H., and D. L. Palmquist. 1993. Diurnal variation of rumen ammonia, serum urea, and milk urea in dairy cows at high and low yields. J. Dairy Sci. 76:475-484.

Harrison, J., R. White, R. Kincaid, E. Block, T. Jenkins, and N. StPierre. 2012. Effectiveness of potassium carbonate sesquihydrate to increase dietary cation-anion difference in early lactation cows. J. Dairy Sci. 95:3919-3925.

Hu, W., and M. R. Murphy. 2005. Statistical evaluation of early- and mid-lactation dairy cow responses to dietary sodium bicarbonate addition. Anim. Feed Sci. Technol. 119:43-54

Jonker, J. S., R. A. Kohn, and R. A. Erdman. 1998. Using milk urea nitrogen to predict nitrogen excretion and utilization efficiency in lactating dairy cows. J. Dairy Sci. 81:2681-2692.

Junghans, P., U. Fischer, and B. Kuklinski. 1999. Body nitrosation potential measured by a novel N-15 breath test. Free Radic. Biol. Med. 27:1302-1307.

Kuehl, R. O. 2000. Design of Experiments: Statistical Principles of Research Design and Analysis. 2nd ed. Display 16.3, page 532. Duxbury Press, Pacific Grove, CA

Kume, S., K. Nonaka, T. Oshita, T. Kozakai, and H. Hirooka. 2008. Effects of urinary excretion of nitrogen, potassium and sodium on urine volume in dairy cows. Livest. Sci. 115:28-33.

Lee, C., and A. N. Hristov. 2013. Short communication: Evaluation of acid-insoluble ash and indigestible neutral detergent fiber as total-tract digestibility markers in dairy cows fed corn silage-based diets. J. Dairy Sci. 96:5295-5299.

Lefcourt, A. M., J. B. Huntington, R. M. Akers, D. L. Wood, and J. Bitman. 1999. Circadian and ultradian rhythms of body temperature and peripheral concentrations of insulin and nitrogen in lactating dairy cows. Domest. Anim. Endocrinol. 16:41-55.

Leiber, F., H.-R. Wettstein, and M. Kreuzer. 2009. Is the intrinsic potassium content of forages an important factor in intake regulation of dairy cows? J. Anim. Physiol. Anim. Nutr. (Berl.) 93:391-399. http://dx.doi.org/10.1111/j.1439-0396.2008.00817.x.

Manalu, W., H. D. Johnson, R.-Z. Li, B. A. Becker, and R. J. Collier. 1991. Assessment of thermal status of somatotropin-injected lactating Holstein cows maintained under controlled-laboratory thermoneutral, hot and cold environments. J. Nutr. 121:2006-2019.

Moorby, J. M., R. J. Dewhurst, R. T. Evans, and J. L. Danelón. 2006. Effects of dairy cow diet forage proportion on duodenal nutrient supply and urinary purine derivative excretion. J. Dairy Sci. 89:3552-3562. http://dx.doi.org/10.3168/jds.S00220302(06)72395-5.

Moore, S. 1968. Amino acid analysis: Aqueous dimethyl sulfoxide as solvent for ninhydrin reaction. J. Biol. Chem. 243:6281-6283.

Murphy, M., M. Åkerlind, and K. Holtenius. 2000. Rumen fermentation in lactating cows selected for milk fat content fed two forage to concentrate ratios with hay or silage. J. Dairy Sci. 83:756-764.

Nennich, T. D., J. H. Harrison, L. M. VanWieringen, N. R. St-Pierre, R. L. Kincaid, M. A. Wattiaux, D. L. Davidson, and E. Block. 2006. Prediction and evaluation of urine and urinary nitrogen and mineral excretion from dairy cattle. J. Dairy Sci. 89:353-364. http://dx.doi.org/10.3168/jds.S0022-0302(06)72101-4.

NorFor (Nordic Feed Evaluation System). 2013. The NorFor feed table. Accessed Dec. 9, 2013. http://feedstuffs.norfor.info/.

Nousiainen, J., K. J. Shingfield, and P. Huhtanen. 2004. Evaluation of milk urea nitrogen as a diagnostic of protein feeding. J. Dairy Sci. 87:386-398.

Ruppert, L. D., J. K. Drackley, D. R. Bremmer, and J. H. Clark. 2003. Effects of tallow in diets based on corn silage or alfalfa silage on digestion and nutrient use by lactating dairy cows. J. Dairy Sci. 86:593-609.

Russell, J. B.. J. D. O'Connor, D. G. Fox, P. J. Van Soest, and C. J. Sniffen. 1992. A net carbohydrate and protein system for evaluat- 
ing cattle diets. 1. Ruminal fermentation. J. Anim. Sci. 70:35513561.

Schneider, P. L., D. K. Beede, C. J. Wilcox, and R. J. Collier. 1984. Influence of dietary sodium and potassium bicarbonate and total potassium on heat-stressed lactating dairy cows. J. Dairy Sci. 67:2546-2553.

Silanikove, N., E. Maltz, A. Halevi, and D. Shinder. 1997. Metabolism of water, sodium, potassium, and chlorine by high yielding dairy cows at the onset of lactation. J. Dairy Sci. 80:949-956.

Spanghero, M., and Z. M. Kowalski. 1997. Critical analysis of N balance experiments with lactating cows. Livest. Prod. Sci. 52:113122 .

Spek, J. W., A. Bannink, G. Gort, W. H. Hendriks, and J. Dijkstra. 2012. Effect of sodium chloride intake on urine volume, urinary urea excretion, and milk urea concentration in lactating dairy cattle. J. Dairy Sci. 95:7288-7298. http://dx.doi.org/10.3168/ jds.2012-5688.

Spek, J. W., A. Bannink, G. Gort, W. H. Hendriks, and J. Dijkstra. 2013a. Interaction between dietary content of protein and sodium chloride on milk urea concentration, urinary urea excretion, renal recycling of urea, and urea transfer to the gastrointestinal tract in dairy cows. J. Dairy Sci. 96:5734-5745. http://dx.doi. org/10.3168/jds.2013-6842.

Spek, J. W., J. Dijkstra, G. van Duinkerken, W. H. Hendriks, and A. Bannink. 2013b. Prediction of urinary nitrogen and urinary urea nitrogen excretion by lactating dairy cattle in northwestern Eu- rope and North America: A meta-analysis. J. Dairy Sci. 96:43104322. http://dx.doi.org/10.3168/jds.2012-6265.

St-Pierre, N. R. 2001. Integrating quantitative findings from multiple studies using mixed model methodology. J. Dairy Sci. 84:741-755.

Technicon Instruments Corp. 1974. Technicon method No. SE40001FD4. Technicon Instruments Corp., Tarrytown, NY.

Udén, P., and T. Eriksson. 2012. Evaluation of some factors influencing the reliability of buffer soluble $\mathrm{N}$ recovery in feeds. Anim. Feed Sci. Technol. 177:218-224. http://dx.doi.org/10.1016/j. anifeedsci.2012.08.007.

Van Soest, P. J. 1994. Nutritional Ecology of the Ruminant. 2nd ed. Cornell University Press, Ithaca, NY.

Volden, H. 2011. NorFor - The Nordic feed evaluation system. EAAP Publication No. 130. Wageningen Academic Publishers, Wageningen, the Netherlands.

Weiss, W. P., L. B. Willett, N. R. St-Pierre, D. C. Borger, T. R. McKelvey, and D. J. Wyatt. 2009. Varying forage type, metabolizable protein concentration, and carbohydrate source affects manure excretion, manure ammonia, and nitrogen metabolism of dairy cows. J. Dairy Sci. 92:5607-5619. http://dx.doi.org/10.3168/jds.20092248.

West, J. W., C. E. Coppock, D. H. Nave, and G. T. Schelling. 1986. Effects of potassium buffers on feed intake in lactating dairy cows and on rumen fermentation in vivo and in vitro. J. Dairy Sci. 69:124-134 